\title{
Hisab Awal Waktu Salat dalam Kitab "al-Khulashah fi al-Awqat al-Syar'iyyah bi al-Lugharitmiyyah” Karya Muhammad Khumaidi Jazry
}

\author{
Rizal Mubit \\ rijal mufid@yahoo.co.id
}

\section{A. Latar Belakang}

Tata cara penentuan waktu salat tidak dijelaskan secara terperinci dalam alQur'an, namun waktu pelaksanaan salat tersebut tidak dapat dilakukan di sembarang waktu. Hal ini sesuai dengan firman Allah dalam surat an-Nisa': 103.

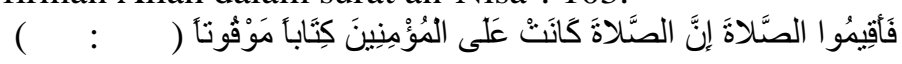

Artinya: "Maka laksanakanlah salat, sesungguhnya salat itu adalah kewajiban yang ditentukan waktunya atas orang-orang yang beriman."1 (QS. An-Nisa': 103).

Ayat tersebut menjelaskan adanya anjuran untuk melaksanakan salat sesuai dengan waktunya. Hal ini berarti tidak dibolehkan untuk menunda dalam menjalankan salat sebab waktu-waktunya telah ditentukan. Salat mempunyai waktu dalam arti ada masa dimana seseorang harus menyelesaikannya. Apabila masa itu berlalu, maka pada dasarnya berlalu juga waktu salat tersebut. Sebagian ayat tersebut juga menunjukkan dalam arti kewajiban yang bersinambung dan tidak berubah, sehingga dalam kalimat ( ) berarti salat adalah kewajiban yang tidak berubah, selalu harus dilaksanakan dan tidak pernah gugur apapun sebabnya. ${ }^{2}$

Kalimat menunjukkan adanya keharusan untuk melaksanakan salat pada waktunya. Menurut Syafi'i, kalimat tersebut berarti adanya suatu kewajiban yang tidak bisa ditunda pelaksanaannya ketika waktu salat sudah datang. ${ }^{3}$ Penutup ayat tersebut, menjelaskan bahwa tidak ada alasan bagi siapapun untuk meninggalkan salat, karena salat merupakan suatu kewajiban yang sudah mempunyai waktu-waktu tertentu. ${ }^{4}$

Ada beberapa anggapan yang menyatakan bahwa cara menentukan waktu salat adalah dengan menggunakan cara melihat langsung pada tanda-tanda alam. Cara tersebut dapat dilakukan dengan seperti menggunakan alat bantu tongkat istiwa, .

\footnotetext{
1 Departemen Agama RI, Al-Qur'an dan Terjemahnya, Surabaya : CV. Pustaka Agung Harapan, 2006, hlm. 125.

${ }^{2}$ M. Quraish Shihab, Tafsir Al-Misbah, Vol. 8, Jakarta : Lentera Hati, Cet 1, 2002, hlm. 570.

${ }^{3}$ Nizham al-Din al-Hasan bin Muhammad bin Husain al-Kummy al-Naesabury, Tafsir Gharaib al-Qur'an wa Raghaib al-Fur'qan, Beirut - Libanon: Dar al-Kutub al-Alamiah, jild II, hlm. 490.

${ }^{4}$ Imam Fakhruddin Muhammad bin Umar bin Husain bin Hasan bin Ali Tamimy al-Bakri alRazy al-Syafi' $i$, Tafsir al-Kabir au Mafatih al-Ghoib, Beirut-Libanon : Dar al-Kutub al-Alamiah, jild VI, hlm. 23.

'Istiwa' (tongkat istiwa') merupakan tongkat yang biasa ditancapkan tegak lurus pada bidang datar di tempat terbuka (sinar matahari tidak terhalang). Kegunaannya untuk menentukan arah secara tepat dengan menghubungkan dua titik (jarak kedua titik ke tongkat harus sama) ujung bayangan tongkat saat matahari disebelah timur dengan ujung bayangan setelah matahari bergerak ke barat. Kegunaan lainnya adalah untuk mengetahui secara persis waktu Zuhur, tinggi matahari, dan -setelah menghitung arah barat- menentukan arah kiblat. Adapun yang disebut dengan istiwa' (waktu istiwa') adalah waktu yang didasarkan pada perjalanan matahari hakiki. Menurut waktu hakiki, matahari berkulminasi pada pukul 12.00 dan berlaku sama untuk setiap hari dan untuk dijadikan waktu ratarata, dikoreksi dengan perata waktu atau equation of time. Uraian selengkapnya baca Susiknan Azhari, Ensiklopedi Hisab Rukyah, yogyakarta ; Pustaka Pelajar, cet II, 2008, hlm. 105.
} 
Sedangkan sebagian yang lain mempunyai pemahaman secara kontekstual, dimana awal dan akhir waktu salat ditentukan oleh posisi matahari dilihat dari suatu tempat di bumi, sehingga metode atau cara yang dipakai adalah hisab (menghitung waktu salat). ${ }^{6}$

Hisab yang dimaksud dalam uraian tersebut adalah perhitungan gerakan benda-benda langit untuk mengetahui kedudukan-kedudukannya pada suatu saat yang diinginkan, maka apabila hisab dikhususkan penggunaannya -misalnya- pada hisab waktu, maka yang dimaksudkan adalah menentukan kedudukan matahari sehingga dapat diketahui kedudukan matahari tersebut pada bola langit di saat-saat tertentu. Hakikat hisab waktu salat berarti menghitung kapan matahari akan menempati posisiposisinya pada waktu-waktu salat. ${ }^{7}$

Tidak hanya berhenti pada dikotomi penentuan dengan tongkat istiwa' dan metode hisab saja. Dalam metode hisab sendiri terdapat rumus yang berbeda dengan penggunaan alat bantu yang berbeda pula.

Alat bantu perhitungan yang biasa digunakan selama ini seperti rubu' mujayyab, daftar logaritma dan kalkulator scientific. Dari semua alat tersebut memiliki kelebihan dan kekurangan masing-masing.

Dalam skripsi ini penulis akan membahas tentang perhitungan waktu salat menggunakan alat bantu tabel logaritma yang terdapat dalam kitab Al-Khulashah $f i$ al-Awqat al-Syar'iyyah bi al-Lugharitmiyyah. Kitab ini sampai sekarang menjadi pedoman pengarangnya, Muhammad Khumaidi Jazry saat mengajar ilmu falak di pondok pesantren Langitan Tuban Jawa Timur dan pondok pesantren Mambaus Sholihin Gresik Jawa Timur.

Proses perhitungan waktu salat dengan alat bantu tabel logaritma bisa dikatakan masih tergolong manual. Akan tetapi dengan demikian orang yang mempelajari ilmu falak dengan alat bantu tersebut tidak terjebak dalam perhitungan instan. Hal inilah yang mendasari pengarangnya untuk tetap mempertahankan penggunaan alat bantu tabel logaritma.

Namun dalam masalah akurasi hasil perhitungan belum diketahui apakah sudah akurat atau belum. Apalagi dalam kitab tersebut mensyaratkan untuk memakai tabel logartima lima desimal. Sementara dengan menggunakan alat bantu kalkulator scientific, pecahan desimalnya melebihi lima angka. Atas dasar inilah kajian waktu salat dalam kitab Al-Khulashah fi al-Awqat al-Syar'iyyah bi al-Lugharitmiyyah perlu untuk diteliti.

\footnotetext{
${ }^{6}$ Ahmad Izzuddin, op.cit, hlm. 52.

7 Badan Hisab Dan Rukyah Departemen Agama, Almanak Hisab Rukyat, Jakarta: Proyek Pembinaan Badan Peradilan Agama Islam, 1981, hlm. 60.
} 


\section{B. Biografi Muhammad Khumaidi Jazry}

Sebelum memasuki proses perhitungan waktu salat, penulis akan menjelaskan tentang Biografi Muhammad Khumaidi Jazry dan karya-karyanya. Nama aslinya adalah Muhammad Khumaidi tanpa Jazry. Penambahan kata Jazry dinisbahkan kepada nama bapaknya, Jazry. Sementara nama ibunya adalah Siti Maisyaroh. ${ }^{8}$

Muhammad Khumaidi lahir di desa Suci Manyar Gresik pada tanggal 19 Agustus 1959. Ia anak pertama dari empat belas bersaudara. Seperti kebanyakan daerah di Gresik, desa Suci juga daerah yang penduduknya kebanyakan adalah santri sehingga nuansa Islam masih mengakar kuat. ${ }^{9}$

Pendidikan pertama Muhammad Khumaidi diperoleh dari orang tua. Sejak usia dini ia sudah mengenal ilmu agama. Kedua orang tuanya adalah tokoh agama yang ternama di desanya. Pada tahun 1965, pada saat berusia enam tahun, Khumaidi masuk ke dalam pendidikan formal di Sekolah Dasar (SD) di Suci. Kehendak orang tua untuk memasukkannya ke sekolah dasar berbeda dengan masyarakat santri kebanyakan. Memasukkan Khumaidi ke SD karena pelajaran agama cukup didapatkannya di rumah. ${ }^{10}$

Pada masa itu orang tua lebih banyak yang memasukkan anaknya untuk belajar di Madrasah Ibtidaiyah (MI). Bukan hanya karena dominasi pelajaran Islam akan tetapi juga disebabkan nuansa politik saat itu. Sekolah dasar diidentikkan dengan sekolah Partai Komunis Indonesia (PKI). Para guru SD memang banyak yang aktif menjadi anggota PKI. Para orang tua tak ingin anaknya masuk PKI. Akibatnya murid SD yang sekelas dengan Khumaidi hanya dua orang. ${ }^{11}$

Setelah menyelesaikan pendidikan dasar, pada tahun 1971 Khumaidi melanjutkan ke Sekolah Menengah Pertama (SMP). Baru setelah memasuki jenjang menengah atas, Khumaidi masuk pondok pesantren Langitan Tuban pada tahun 1974. Pada saat itu pengasuhnya adalah almahrum KH. Marzuki Zahid dan almarhum KH. Abdullah Faqih. Karena kemampuannya dalam bidang agama sudah baik, pada tahun 1978 ia mendapat perintah langsung dari Kiai Marzuki untuk mengajar. Pada tahun yang sama Khumaidi mengikuti ujian persamaan SMA. ${ }^{12}$

Ketika muda, Muhammad Khumaidi sangat mencintai ilmu pengetahuan terutama agama. Meski sudah nyantri di pesantren Langitan, ia sering mengikuti pesantren kilat. Bahkan ilmu falak pun dari pesantren kilat. Keinginannya belajar ilmu falak karena ketertarikannya terhadap Faraid (ilmu waris). Hobi menghitung dalam ilmu Faraid dirasa belum cukup untuk memenuhi hasratnya untuk menghitung. Akhirnya dia memutuskan untuk belajar ilmu falak. ${ }^{13}$

Khumaidi pertama kali belajar ilmu falak kepada Kiai Rodli salah satu ahli falak dari daerah Manyar Gresik. Pada tahun 1984 ia memperdalam falak kepada Kiai Nawawi di daerah Jamsaren Kediri dengan sistem pesantren kilat. Kiai Nawawi adalah putra Kiai Yunus, guru dari penulis kitab Sirojut Tholibin Kiai Ihsan Jampes Kediri. Kitab yang dipakai bahan ajar oleh Kiai Yunus adalah kitab Tashilul Mitsal karangan Kiai Yunus, ayah Kiai Nawawi. Sampai saat ini kitab tersebut baru ditulis tangan dan tersimpan di perpustakaan pribadi Muhammad Khumaidi. Menurut

\footnotetext{
${ }^{8}$ Wawancara dengan KH. Muhammad Khumaidi Jazry pada hari Ahad tanggal 8 April 2012 di kediamannya.

${ }^{9}$ Ibid

${ }^{10}$ Ibid

11 Ibid

12 Ibid

${ }^{13}$ Ibid
} 
keterangan Muhammad Khumaidi, data-data kitab tersebut asli dari penelitian Kiai Yunus bukan data yang diambil dari kitab lain seperti kitab falak kebanyakan. Selain mengajar kitab Tashil al-Mitsal, Kiai Nawawi juga mengajari Muhammad Khumaidi kitab Risalat al-Qomaroini, kitab itu pun sampai sekarang masih dalam bentuk tulisan tangan. ${ }^{14}$

Kecintaannya terhadap ilmu agama memberikan semangat Khumaidi untuk merantau mencari guru-guru atau Kiai yang ahli dalam bidang tertentu. Selain mengaji pada Kiai Nawawi, ia juga belajar kitab Syamsul Hilal dan Nurul Anwar langsung kepada pengarangnya, Kiai Noor Ahmad Jepara. Ini juga dilakukan dengan pesantren kilat dengan beberapa santri pesantren Langitan. ${ }^{15}$

Setelah belajar dari Kiai Noor Ahmad, Khumaidi dan santri-santri Langitan berkeinginan untuk belajar falak kepada Kiai Turaichan Kudus. Namun keinginan tersebut tidak terealisasi karena Kiai Turaichan wafat tidak lama setelah Khumaidi mengutarakan keinginannya untuk belajar falak kepada Kiai Turaichan. ${ }^{16}$

Setelah belajar dari para Kiai dengan pesantren kilat, Muhammad Khumaidi belajar sendiri kitab-kitab falak seperti ad-Durus al-Falakiyah, Badi'tatul Mitsal, kedua kitab tersebut karya Kiai Ma'sum Bin Ali. Fathur Rouf al-Mannan Abdul Jalil bin Abdul Hamid, Ittifaq dzatil bain karya Kiai Zubair Bungah Gresik dan kitab-kitab falak lainnya. ${ }^{17}$

Ilmu falak yang didapatkan dari merantau dan belajar sendiri berbuah hasil yang baik. Di kalangan pesantren Langitan, ia diakui sebagai santri yang ahli di bidang falak sehingga dia mendapat mandat untuk mengajar falak di pondok pesantren Langitan. Pada tahun 1985 Muhammad Khumaidi sudah mengajarkan falak di Langitan. Sampai sekarang ia mengajar falak. Namun karena domisilinya pindah ke Gresik, Kiai Khumaidi hanya mengajar Falak pada hari Selasa dan Ahad. ${ }^{18}$

Kiai Khumaidi juga sempat mengajar falak di pondok pesantren Mambaus Sholihin Suci Manyar Gresik selama beberapa tahun. Terakhir mengajar falak di pondok Mambaus Sholihin pada tahun 2009.

Muhammad Khumaidi tidak hanya ahli di bidang falak. Ia juga menguasai ilmu hadis, nahwu, sharaf, fikih dan lainnya. Keluasan yang dimilikinya membuat ia dipercaya oleh KH Masbuchin Faqih, pengasuh pondok pesantren Mambaus Sholihin untuk menjadi kepala madrasah aliyah padahal saat itu ia masih berdomisili di Langitan sehingga dia harus pulang pergi dari Tuban ke Gresik. ${ }^{19}$

Selain menjadi pengajar, Khumaidi juga aktif dalam kepengurusan NU. Dimulai menjadi pengurus ranting NU desa Suci, lalu menjadi sekretaris MWC NU Manyar periode 1991-1996. Pada tahun 1997 dia dipercaya menjadi Ra'is MWC hingga tahun 2002. Sekarang dia masih menjabat wakil rais pengurus cabang NU Gresik periode 2010-2015 dan wakil sekretaris Pengurus Wilayah Jam'iyyah thariqah periode $2009-2014 .^{20}$
${ }^{14}$ Ibid
15 Ibid
16 Ibid
17 Ibid
18 Ibid
19 Ibid
${ }^{20}$ Ibid 


\section{Karya Muhammad Khumaidi Jazry}

Setelah lulus dari pesantren Langitan, Muhammad Khumaidi tidak langsung kembali ke kampung halaman. Dia tinggal di pondok dengan kapasitas menjadi ustadz. Keluasan pengetahuan yang dimiliki, menjadikannya menjadi ustadz yang mengajar dalam beberapa bidang. Dalam masa-masa menjadi tenaga pengajar tersebut, ia produktif menulis kitab untuk dijadikan buku pegangan bagi para santri. Hanya saja karena kesibukan dan kondisi fisik Khumaidi sekarang tak bisa menulis seproduktif seperti waktu muda. ${ }^{21}$

Adapun kitab yang pernah ditulis Muhammad Khumaidi Jazry adalah sebagai berikut:

1. Uddat al-Farid

Kitab ini menjelaskan tentang ilmu waris. kitab Uddat al-Farid menjadi bahan ajarnya saat mengajar Faraid di pondok pesantren Langitan. Sampai sekarang kitab ini masih dalam bentuk tulisan tangan.

\section{Risalah al-Mahidh}

Kitab ini berisi penjelasan tentang darah perempuan. Haid, Nifas dan Istihadhoh. Kitab ini juga menjadi bahan ajar di pondok pesantren Langitan.

\section{Tarjamah Jauharul Maknun}

Kitab Jauharul Maknun adalah kitab yang menjelaskan ilmu balaghah yang ditulis oleh Abdurrahman al-Ahdhari. Terjemah kitab Jauharul Maknun yang ditulis Muhammad Khumaidi sebenarnya tidak hanya berupa terjemahan saja. Tetapi ada penjelasan yang ditulis Muhammad Khumaidi sendiri. Kitab ini Tarjamah Jauharul Maknun juga menjadi bahan ajar Muhammad Khumaidi saat mengajar di Langitan.

4. Tarjamah Imrity

Kitab ini merupakan terjamahan dari kitab nahwu Nadhom Imrity. Di dalam Tarjamah Imrity juga terdapat penjelasan tambahan dari Khumaidi jazry. Sampai sekarang kitab ini masih dalam tulisan tangan.

\section{Tarjamah Maqsud}

Kitab ini merupakan terjamahan dari kitab sharaf Nadhom Maqsud. Di dalam Tarjamah maqsud juga terdapat penjelasan tambahan dari Khumaidi jazry. Sampai sekarang kitab ini masih dalam tulisan tangan.

\section{Tarjamah Mutammimah}

Kitab ini merupakan terjamahan dari kitab nahwu Mutammimah. Di dalam Tarjamah Mutammimah. Sampai sekarang kitab ini masih dalam tulisan tangan.

\section{Al-Khulashah}

Kitab ini awalnya catatan-catatan yang digunakan oleh Khumaidi saat mengajar alfiyah di pondok pesantren Langitan. Atas inisiatif para santri, kumpulan bahan ajar tersebut dibukukan dan menjadi kitab pegangan di pesantren Langitan. Karena mudah dipahami dan dipelajari kitab ini juga jadi pegangan santri dalam belajar alfiyah di Mambaus Sholihin.

8. Al-Khulashah fi al-Awqat al-Syar'iyyah bi al-Lugharitmiyyah

Kitab ini satu-satunya kitab falak yang ditulis oleh Muhammad Khumaidi Jazry. Kitab ini juga menjadi bahan ajar selama mengajar falak di Langitan dan pondok pesantren Mambaus Sholihin.

Semua kitab yang ditulis oleh Muhammad Khumaidi masih ditulis tangan. Sebagian besar tulisannya dengan menggunakan arab pegon. Kitab-kitab tersebut

\footnotetext{
21 Ibid
} 
tidak dikaji di kalangan umum akan tetapi hanya dipakai oleh kalangan pesantren tempat ia mengajar. ${ }^{22}$

\section{Proses Perhitungan Awal Waktu Salat Dalam Kitab Al-Khulashah Fi al- Awqat al-Syar'iyyah Bi al-Lugharitmiyyah}

Sebelum mengetahui Proses perhitungan waktu salat dalam kitab Al-Khulashah fi al-Awqat al-Syar'iyyah bi al-Lugharitmiyyah, ada beberapa data dan istilah yang harus diketahui untuk menghitung waktu salat dengan metode yang digunakan dalam Kitab Al-Khulashah fi al-Awqat al-Syar'iyyah bi al-Lugharitmiyyah:

1. Bu'du al-darajah

$B u$ 'du al-darajah ialah jarak matahari dari katulistiwa sepanjang garis ekliptika. Untuk mengetahuinya terlebih dahulu harus diketahui posisi matahari berada di buruj dan berapa nilai derajatnya. Pada tanggal 21 Maret matahari berada di buruj haml (tepat di katulistiwa). Pada saat itu $b u^{\prime} d u$ al-darajah bernilai $0^{\circ}$. Kemudian pada tanggal 27 Maret matahari tiba di buruj Hamal $6^{\circ}$. Bu'du al-darajah matahari senilai $6^{\circ}$ di sebelah utara. Pada bulan 21 Juni tiba di buruj Sarathan $0^{\circ}$ (letak terjauh matahari berada di utara katulistiwa). Pada waktu itu bu'du al-darajah $90^{\circ}$ sebelah utara. $^{23}$

Kemudian pada tanggal 27 juni matahari tiba di buruj Sarathan $6^{\circ}$. Pada saat itu $B u^{\prime} d u$ al-darajah ialah $90^{\circ}-6^{\circ}=84^{\circ}$. Karena sesudah matahari tiba di buruj saratan $0^{\circ}$ kemudian mengisar ke selatan mendekati garis katulistiwa, berarti makin berkurang dari $90^{\circ}$. Pada tanggal 27 september matahari tiba di buruj Mizan $0^{\circ}$ tepat di garis katulistiwa. Bu'du al-darajah adalah $0^{\circ}$ kemudian pada tanggal 30 September tiba di buruj Mizan $8^{\circ}$. Bu'du al-darajah adalah $8^{\circ}$ sebelah selatan garis katulistiwa. Pada tanggal 24 Oktober tiba di buruj Aqrab. Bu'du al-darajah adalah $30^{\circ}$ sebelah selatan. Kemudian pada tanggal 30 oktober tiba di buruj Aqrab $6^{\circ}$. Pada waktu itu $B u^{\prime} d u$ al-darajah ialah $30^{\circ}+6^{\circ}=36^{\circ}$ derajat di sebelah selatan. ${ }^{24}$

Pada tanggal 21 September matahari tiba di buruj Jadyu $0^{\circ}$ (posisi terjauh matahari di selatan katulistiwa). Bu'du al-darajah adalah $90^{\circ}$. Pada tanggal 30 Desember tiba di buruj Jadyu $9^{\circ}$. Berarti Bu'du al-darajah adalah $90^{\circ}-9^{\circ}=81^{\circ}$ sebelah selatan karena sesudah tiba di buruj $0^{\circ}$ tersebut matahari berjalan mengisar ke utara mendekati katulistiwa. Berarti semakin berkurang dari 90 derajat. Demikianlah seterusnya. $^{25}$

2. 'Ard al-Balad (Lintang Tempat) dan Thul al-Balad (Bujur tempat)

Lintang tempat adalah jarak sepanjang meridian bumi diukur dari katulistiwa sampai suatu tempat yang dimaksud. Dalam bahas inggris disebut dengan longitude. Bujur tempat adalah jarak dari tempat yang dimaksud ke garis bujur yang melalui kota Greenwich dekat London. Dalam bahasa Inggris disebut dengan Latitude.

\footnotetext{
22 Ibid

${ }^{23}$ KR. Muhamad Wardan, op. cit., hlm. 67.

24 Ibid

${ }^{25}$ Ibid
} 
Untuk mencari data lintang tempat dan bujur tempat suatu daerah dapat diketahui dengan melihat data yang telah disediakan dalam Kitab Al-Khulashah fi alAwqat al-Syar'iyyah Bi al-Lugharitmiyyah pada halaman 32 dan 33

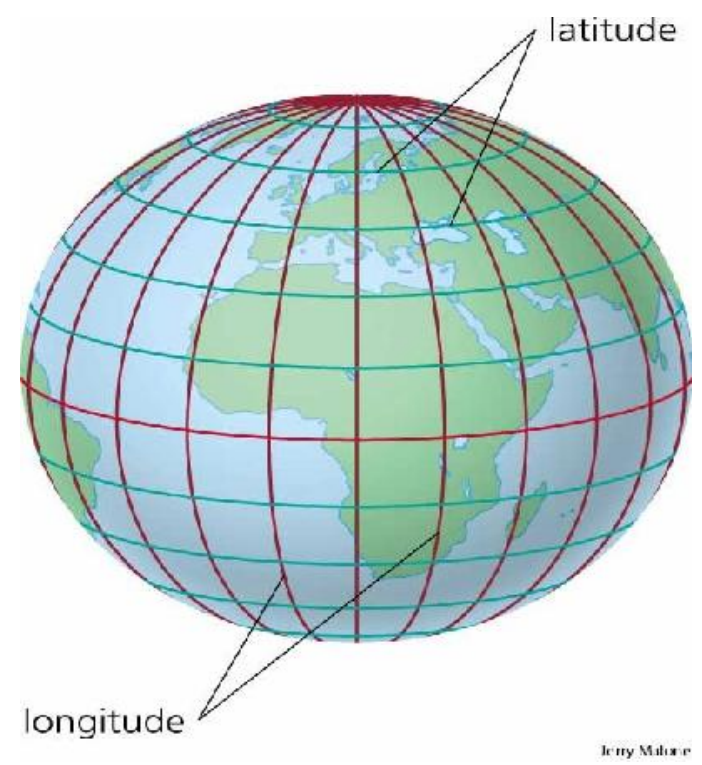

Gambar 1. Lintang (Latitude) dan bujur (Longitude)

\section{Tafawut}

Tafawut berasal dari bahasa Arab, yang artinya adalah selisih. Yakni selisih antara dua data. Tafawut ini digunakan pula sebagai harga selisih hari antara umur satu bulan dengan tanggal permulaan zodiak yang ada pada bulan itu. ${ }^{26}$ Misalnya umur bulan Maret adalah 31 hari, sementara permulaan zodiak Aries adalah 21 Maret. Jadi tafawutnya adalah 31-21=10. Tafawut ini digunakan untuk menghitung perkiraan kedudukan matahari pada ekliptika.

4. Al-Mail al-Awwal

Al-mail al-awwal atau yang disebut dengan mail saja ialah jarak matahari (benda langit) dari katulistiwa dihitung dengan derajat sepanjang dairah mail (lingkaran deklinasi) yang ditempati pada waktu itu. ${ }^{27}$

\section{Bu'du al-Quthr}

Yang dimaksud $B u$ 'du al-quthr matahari adalah busur yang dihitung dari ufuk tempat matahari terbit atau terbenam sampai dengan garis tengah lintasan matahari yang membagi lintasan itu menjadi dua bagian sama besar (bagian atas dan bawah). ${ }^{28}$

$B u^{\prime} d u$ al-quthr di atas ufuk adalah positif sedangkan yang berada di bawah ufuk adalah negatif. Bu'du al-quthr positif jika deklinasi searah yaitu deklinasi dan lintang tempat sama-sama positif atau sama-sama negatif. Bu'du al-quthr negatif jika deklinasi dan lintang tempat searah, yaitu manakala deklinasinya positif dan lintang tempatnya negatif atau sebaliknya. ${ }^{29}$

Cara mencarinya adalah Log sin al-mail al-awwal dijumlahkan dengan log sin lintang tempat. Hasilnya adalah $\log \sin b u^{\prime} d u$ al-quthr. Contoh mencari bu'du al-

\footnotetext{
${ }^{26}$ Muhyiddn Khazin, Kamus Ilmu Falak, Yogyakarta: Buana Pustaka, 2005, hlm. 79

27 KR. Muhamad Wardan, op. cit, hlm. 42.

28 Slamet Hambali, Ilmu Falak 1, Penentuan Awal Waktu Shalat \& Arah Kiblat Seluruh Dunia, Semarang: Program Pasca Sarjana IAIN Walisongo Semarang, 2011, hlm. 66

${ }^{29}$ Ibid, hlm. 65-66
} 
quthr pada tanggal 21 Juni di kota Semarang. Lintang Semarang 06 ${ }^{\circ} 59^{\prime}$ dan al-mail al-awwal $23^{\circ} 27^{\prime} .^{30}$

6. Ashl al-muthlaq

Ashl al-muthlaq adalah jarak yang dihitung dari titik kulminasi atas sampai pada titik pertemuan antara garis horizon dengan garis tengah lintasan matahari yang menghubungkan titik kulminasi atas dengan titik kulminasi bawah. Ashl al-muthlaq selalu positif, yaitu selalu di atas ufuk. ${ }^{31}$

Cara mencari Ashl al-mutlaq adalah Log sin tamam $^{32}$ al-mail (complement deklinasi $=90^{\circ}$-deklinasi) dijumlahkan dengan logaritma sinus tamam al-' $\operatorname{ardh}$ (complement lintang tempat $=90^{\circ}$ - lintang tempat ).

7. Nisfu al-Fudlah

Nisfu al-Fudlah yaitu waktu yang membedakan antara setengah busur siang rata-rata dengan setengah busur siang yang sebenarnya. ${ }^{33}$

Cara mencari Nisfu al-fudlah adalah logaritma sinus Bu'du al-quthr dikurangi logaritma sinus al-ashl al-muthlaq.

8. Qous al-Nahar

Qousun Nahar atau busur siang adalah busur sepanjang lingkaran suatu benda langit diukur dari titik terbit melalui titik kulminasi atas hingga titik terbenam.

30 Data lintang tempat diambil dari kitab al-Khulashah fi al-Awqat al-Syar'iyyah bi allugharitmiyyah dan dan data al-mail al-awwal diambil dari kitab Syawariq al-Anwar.

31 Slamet Hambali, op. cit, hlm. 66

32 Penyiku, yaitu tambahan sudut untuk menjadi siku-siku. Dalam bahasa inggris disebut Compliment. Lihat. Susiknan Azhari, Ibid, hlm. 210.

33 Slamet Hambali, op. Cit, hlm. 67 
Keterangan gambar

A-A1 = al-mail al-awwal selatan

A-A2 = al-mail- al-awwal utara

A1-B2 = al-asl al-mutlak di atas ufuk

A2-B2 = al-asl al-mutlak di bawah ufuk

B1-E1 = bu'du al-quthr di atas ufuk

B1-E1 = bu'du al-quthr di bawah ufuk

D1-F1 = nisfu al-fudlah di atas ufuk

D1-F1 = nisfu al-fudlah di bawah ufuk

9. Ghayah al-Irtifa'

Ghayah al-Irtifa' adalah busur yang terbentuk dari diameter bola langit yang berada di antara titik tempat benda langit dan ufuk yang terdekat atau titik kulminasi teratas dari ufuk yang terdekat dihitung dari dairah nisfi an nahar (garis lintasan besar yang memisah antara barat dan timur melalui kedua ufuk dan kutub alam). ${ }^{34}$ Di bawah ini adalah contoh gambar kulminasi.

Gambar 3. Kulminasi matahari (ghayah al-irtifa')

\section{B}

A

$\mathrm{kul}$

B

Keterangan:

A. Kulminasi Atas

B. Kulminasi Bawah

Cara mencari Ghayah al-Irtifa' adalah:

a) Menentukan tamam Lintang tempat yang akan dicari, yakni $90^{\circ}$ dikurangi dengan lintang tempat.

b) Menjumlahkan al-mail al-awal pada tamamnya Lintang tempat,

c) Hasil dari penjumlahan tersebut adalah Ghayah al-Irtifa'.

10. Ashl al-Mu'addal

Adalah garis yang ditarik dari titik pusat suatu benda langit tegak lurus pada bintang kaki langit. Garis itu adlah garis proyeksi benda langit kepada bidang kaki langit. ${ }^{35}$

Cara mengetahui nilai Ashl al-Mu'adal adalah:

a) Jumlahkan nilai logaritma sinus irtifa' (tinggi kulminasi) dengan $b u$ 'du alQutur

b) Hasil penjumlahan tersebut adalah ashl al-mutlak.

11. Daqo'iq al-tamkiniyyah

Daqo'iq al-tamkiniyyah adalah tenggang waktu yang diperlukan oleh matahari sejak piringan atasnya menyentuh ufuk hakiki hingga terlepas dari ufuk mar' $^{\prime 36}$.

12. Hisshath al-Fajar

Hisshath al-fajar adalah cahaya fajar. Yaitu tenggang waktu yang dihitung dari terbit fajar (subuh) sampai matahari terbit. ${ }^{37}$

\footnotetext{
34 Ibid

35 Ibid

${ }^{36}$ Muhyiddin Khazin, op. cit., hlm. 19

${ }^{37}$ Ibid, hlm. 30
} 


\section{Hisshath al-Syafaq}

Hisshath al-syafaq adalah cahaya senja. Yaitu tenggang waktu yang dihitung dari terbenamnya matahari hingga hilangnya mega merah di ufuk langit sebelah barat.

Setelah mengetahui data-data di atas, perhitungan waktu salat dapat diketahui. Adapaun langkah-langkah untuk menentukan waktu salat adalah sebagaimana berikut:

\section{Proses Perhitungan Awal Waktu Zuhur}

Rumus untuk mengetahui waktu dhuhur adalah jam 12 dikurangi daqaiq altamkiniyyah (adakalanya 4 menit, 3 menit 30 detik atau 3 menit).

\section{Proses Perhitungan Awal Waktu Ashar}

A. Jika muwafaqah ${ }^{38}$ antara al-mail al-awwal dan 'ard al-balad maka tamam 'ard al-balad (complement lintang $=90^{\circ}$ - lintang tempat) ditambah dengan al-Mail al-Awwal. Jika mukhalafah maka tamam 'ard al-Balad dikurangi dengan al-Mail al-Awwal. Hasilnya disebut al-ghayah. Ketika muwafaqah biasanya hasilnya melebihi $90^{\circ}$. Jika terjadi demikian maka kelebihannya digunakan untuk mengurangi $90^{\circ}$. Sisa tersebut adalah al-ghayah. Misal menghitung waktu salat pada 21 Juni dengan data lintang Semarang $06^{\circ} 59^{\prime}$. Pada tanggal 21 Juni posisi matahari berada di utara. Maka pada tanggal 21 Juni berlaku mukhalafah.

B. Merubah bilangan al-ghayah menjadi bernilai cotg (cotangens) dengan menggunakan tabel logaritma dalam daftar 3 kolom cotg.

C. Merubah nilai al-qomah yakni $45^{\circ}$ (nilai al-qomah merupakan rumus tetap) dijadikan cotg.

D. Nilai cotg al-ghayah ditambahkan nilai cotg alqomah. Hasilnya disebut dengan irtifa' al-ashar.

E. Lalu nilai cotg irtifa' al-ashar dijadikan nilai qous. Setelah itu diubah menjadi sin (sinus) dalam daftar logaritma nomor tiga.

F. Mencari ashl al-muaddal dengan cara menjumlahkan nilai sin bu'du al-qutr dengan nilai sin irtifa' al-Asar. Jika mukhalafah maka ditambahkan, jika muwafaqah maka dikurangi. Hasil penjumlahan tersebut nilainya dijadikan qous.

G. $\log \sin$ ashl al-muaddal dikurangi nilai $\log \sin$ al-ashl al-mutlak. Lalu nilainya dijadikan qous. Hasilnya disebut tamam fadlu ad-dair (complement fadlu ad dair).

H. Fadlu ad-dair ${ }^{39}$ dapat diketahui dengan $90^{\circ}$ dikurangi tamam fadlu ad-dair.

I. Setelah itu waktu ashar dapat diketahui dengan cara mengalikan Fadlu ad-dair tersebut dikalikan 4 menit (kaidah).

${ }^{38}$ Persamaan kedudukan Lintang tempat (LM) dengan Deklinasi Matahari (D)

39 Sudut waktu, yakni sudut pada titik kutub langit yang dibentuk oleh perpotongan antara lingkaran meridian dengan lingkaran waktu yang melalui suatu objek tertentu di bola langit. Sudut ini biasanya ditandai dengan huruf $t$. Dikatakan sudut jam (sudut waktu), karena bagi semua benda langit yang terletak pada lingkaran waktu yang sama berlaku ketentuan jarak waktu yang memisahkan mereka dari kedudukan mereka pada saat berkulminasi adalah sama. Dengan kata lain, benda-benda langit yang terletak pada lingkaran waktu yang sama berkulminasi pada waktu yang sama pula. Besarnya sudut waktu itu menunjukkan berapakah jumlah waktu yang memisahkan benda langit yang bersangkutan dan kedudukannya sewaktu berkulminasi. Sudut waktu dinamakan positif jika benda langit bersangkutan di belahan langit sebelah barat dan dinamakan negatif jika benda langit bersangkutan di belahan langit sebelah timur. Lihat Susiknan Azhari, op. cit, hlm. 195 


\section{Proses Perhitungan Awal Waktu Maghrib}

A. Mencari nisfu qousin nahar hakiky dengan cara nisfu al-fudlah dikurangi $90^{\circ}$ jika mukhalafah. Jika muwafaqah maka nisfu al-fudlah ditambahkan $90^{\circ}$.

B. Nisfu qousin nahar hakiky dikalikan 4 menit. Hasilnya disebut Saah qousin nahar haqiqy.

C. Saah qousin nahar haqiqy ditambah daqaiq al-tamkiniyyah. Hasilnya adalah waktu maghrib.

\section{Proses Perhitungan Awal Waktu Isya}

A. Menentukan nilai log sin dari irtifa' al-isya (ketinggian matahari waktu isya) $17^{\circ}$.

B. Mencari al-Baqy. Caranya mengurangkan angka log sin irtifa' al-isya dengan angka logaritma sinus al-Asl al-Mutlak. Hasil pengurangan tersebut dijadikan qous.

C. Nilai al-baqy dan nilai nisfu al-fudlah dijadikan sin.

D. Mencari nilai sin Makan dengan cara menjumlahkan sin al-baqy dengan sin nisfu al-fudlah. Jika mukhalafah maka dikurangi jika muwafaqah maka ditambah.

E. Mencari hisshath al-syafaq. Caranya nilai makan dijadikan qous lalu dijumlahkan dengan nilai qous nisfu al-fudlah. Jika mukhalafah maka ditambah jika muwafaqah maka dikurangi.

F. Mencari hasil al-dhorb. Caranya hisshath al-syafaq dikalikan 4 menit.

G. Hasil al-dhorb ditambahkan waktu maghrib. Hasilnya menunjukkan waktu Isya.

\section{Proses Perhitungan Awal Waktu Subuh}

A. Menentukan nilai log sin dari irtifa' al-shubuh (ketinggian matahari waktu subuh) $19^{\circ}$.

B. Mencari al-baqy. Caranya mengurangkan angka log sin ketinggian matahari dengan angka log sin al-ashl al-mutlak. Hasil pengurangan tersebut dijadikan nilai qous.

C. Nilai al-baqy dan nilai nisfu al-fudlah dijadikan sinus.

D. Mencari nilai sin Makan dengan cara menjumlahkan sin al-baqy dengan sin nisfu al-fudlah. Jika mukhalafah maka dikurangi jika muwafaqah maka ditambah.

E. Mencari hisshat al-fajar. Caranya nilai derajat makan dijumlahkan dengan derajat nisfu al-fudlah. Jika mukhalafah maka ditambah jika muwafaqah maka dikurangi.

F. Mencari sa'ah hisshat al-fajar. Caranya hishsat al-fajar dikalikan 4 menit.

G. Jam 12 (kaidah) dikurangi waktu Maghrib. Sisanya disebut thulu' al-syams.

H. Thulu' al-syams dikurangi sa'ah hisshat al-fajar. Sisanya menunjukkan waktu subuh.

\section{E. Analisis Metode Penentuan Awal Waktu Salat dengan Kitab Al-Khulashah Fi} al-Awqat al-Syar'iyyah Bi al-Lugharitmiyyah

Kitab Al-Khulashah $F i$ al-Awqat al-Syar'iyyah Bi al-Lugharitmiyyah merupakan salah satu kitab falak yang alat bantu perhitungannya menggunakan tabel 
logaritma lima desimal. Adapun alasan penggunaan alat bantu tersebut tersebut karena pada masa dahulu masih minim penggunaan kalkulator scientific sehingga untuk mempermudah dalam perhitungan digunakan sistem logaritma. Sampai saat ini perhitungan dengan alat bantu tabel logaritma masih digunakan di beberapa pesantren.

Untuk memudahkan penulis dalam menganalisis metode penentuan waktu salat dalam kitab Al-Khulashah Fi al-Awqat al-Syar'iyyah Bi al-Lugharitmiyyah, maka dalam skripsi ini penulis membagi menjadi dua bagian.

\section{Konsep Perhitungan}

Setelah menganalisis proses perhitungan dan hasil perhitungan dalam kitab tersebut, penulis dapat mengambil kesimpulan bahwa perhitungan waktu salat dengan menggunakan alat bantu tabel logaritma lima desimal amatlah rumit. Masih banyak bahasa-bahasa falak yang belum diterjemahkan ke dalam bahasa Indonesia sehingga selain memperrumit proses perhitungan juga mempersulit pemahaman.

Proses perhitungan waktu salat dalam kitab ini juga memerlukan ketelitian dan kejelian karena kitab ini masih sangat manual dalam mencantumkan angka-angka desimal. Jika salah satu angka saja akan terjadi kesalahan fatal yang mengakibatkan hasil perhitungan yang tidak benar.

Karena dalam nilai bilangan dalam tabel logaritma selalu positif maka dalam rumus tersebut terjadi konsep muwafaqah dan mukhalafah. Penerapannya dalam kitab ini adalah jika terdapat nilai negatif pada lintang tempat atau deklinasi matahari, maka perhitungannya tetap bernilai positif. Hanya saja, nilai negatif/positif tersebut dapat membedakan rumus yang digunakan dalam perhitungannya, yakni dapat menggunakan muwafaqah dan mukhalafah.

Perhitungan waktu salat dalam kitab ini dimulai dengan perhitungan waktu maghrib karena dalam perhitungan waktu Isya dan waktu subuh dibutuhkan hasil waktu maghrib. Waktu Isya baru bisa diketahui ketika hasil al-dhorb ditambah dengan waktu maghrib. Sementara dalam rumus perhitungan waktu subuh, waktu maghrib dibutuhkan untuk mencari thulu' al-syams waktu matahari terbit. Selanjutnya thulu' al-syams dikurangi sa'ah hisshath al-fajar.

Kitab ini juga belum mencantumkan data-data al-mail al-awwal oleh karena itu untuk mencari data-datanya diperlukan kitab lain. Dalam hal ini kitab Syawariq alanwar karya Noor Ahmad dapat dijadikan pegangan untuk mencari data-data al-mail al-awwal.

Sebenarnya perhitungan waktu salat bisa dimulai dengan mencari waktu salat Dhuhur dahulu seperti dalam kitab-kitab lainnya. Akan tetapi karena pencarian nisfu al-fudlah, bu'du al-quthr, al-ashl al-mutlak, dan al-mail al-awwal dimasukkan dalam rumus mencari waktu salat maghrib maka penulis kitab meletakkan pencarian waktu maghrib berada di awal perhitungan agar pencarian waktu salat yang lain bisa diketahui. Tujuan penulis kitab melakukan hal tersebut adalah untuk mempersingkat perhitungan. ${ }^{40}$

Dari penjelasan di atas dapat diketahui bahwa nisfu al-fudlah, bu'du al-quthr, al-ashl al-mutlak, al-mail al-awwal tidak hanya dibutuhkan walam pencarian waktu salat maghrib akan tetapi juga dibutuhkan dalam perhitungan waktu Isya dan waktu subuh, dan waktu ashar. Waktu subuh dan Isya membutuhkan data nisfu al-fudlah dan

${ }^{40}$ Wawancara dengan KH. Muhammad Khumaidi Jazry pada hari Ahad tanggal 8 April 2012 di kediamannya. 
al-ashl al-mutlak sedangkan rumus waktu ashar membutuhkan data bu'du al-quthr dan al-ashl al-mutlak.

Untuk mempermudah dalam proses perhitungan, penulis membuat rumusan baru dengan cara mengkategorikan data-data yang diperlukan dalam proses perhitungan sendiri. Seperti bu'du al-darajah, nisfu al-fudlah, bu'du al-quthr dan alashl al-mutlak. Tujuannya agar tidak terjadi tumpang tindih dalam perhitungan. Seperti dalam pergitungan waktu salat Maghrib. Dalam perhitungan tersebut juga disebutkan bagaimana cara mencari bu'du al-darajah, nisfu al-fudlah, bu'du al-quthr dan al-ashl al-mutlak. Padahal data-data tersebut adalah data mutlak yang dibutuhkan untuk menghitung waktu salat lainnya. Tidak hanya salat maghrib.

Akan tetapi dalam perhitungan salat ashar penulis tidak memiskahkan cara mencari al-ashl al-muaddal karena data itu hanya dibutuhkan dalam mencari waktu ashar saja. Selain itu dalam hal ketinggian matahari, waktu ashar juga memiliki perbedaan terendiri dibanding waktu salat lain karena waktu ashar masuk ketika tinggi bayangan suatu benda sama dengan tinggi orang benda tersebut. Karena itu tidak ada patokan pasti berapa ketinggian matahari salat ashar.

Berbeda dengan salat maghrib yang bisa diketahui dengan terbenamnya matahari. Karena matahari terbenam dalam waktu yang selalu sama yakni ketika piringan atas matahari terbenam sepenuhnya. Sementara waktu isya terjadi saat mega merah telah hilang. Dalam kitab ini disebutkan ketinggian matahari pada saat tersebut ialah $17^{\circ}$ di bawah ufuk. Untuk ketinggian matahari waktu subuh dipastikan pada saat matahari berada pada $19^{\circ}$ di bawah ufuk. Karena kitab ini masih menggunakan tabel logaritma, maka penyebutan ketinggian matahari di bawah ufuk tidak ditulis dengan tanda negatif (-). Dalam buku-buku falak pada umumnya, kriteria ketinggian matahari waktu Isya yang disebutkan adalah $-18^{\circ}$ dan waktu Subuh adalah $-20^{\circ}$.

Perhitungan awal waktu salat dalam kitab ini tidak memperhitungkan perata waktu atau equation of time ${ }^{41}(e)$. Padahal penggunaan data equation of time dibutuhkan dalam perhitungan waktu salat untuk saat kulminasi Matahari bagi daerahdaerah di sekitar bujur Waktu Indonesia Barat (WIB). Data equation of time juga diperlukan untuk mengkonversi waktu kulminasi matahari dari waktu matahari hakiki ke waktu pertengahan setempat, atau waktu pertengahan daerah. ${ }^{42}$

Waktu pertengahan tersebut biasanya disesuaikan dengan waktu daerah, yaitu waktu-waktu yang telah ditetapkan menurut bujurnya, sehingga dengan demikian untuk tempat-tempat yang berada di sebelah timur bujur yang dijadikan pedoman waktu daerah disesuaikan dengan mengurangi selisih waktu sebanyak selisih bujurnya. Bagi tempat-tempat yang bujurnya berada di sebelah barat bujur tempat yang dijadikan pedoman ditambahkan dengan selisih bujur tersebut. ${ }^{43}$

Perhitungan dalam kitab Al-Khulashah fi al-Awqat al-Syar'iyyah bi alLugharitmiyyah masih menggunakan waktu istiwa. Untuk mengetahui waktu daerah tertentu dibutuhkan data-data bujur-bujur daerah yang akan digunakan, misalnya Waktu Indonesia Barat $($ WIB $)=105^{\circ}$, Waktu Indonesia Tengah $($ WITA $)=120^{\circ}$ dan Waktu Indonesia Timur $($ WIT $)=135^{\circ}$. Setelah mengetahui bujur daerah tersebut lalu

${ }^{41}$ Equation of time yang disebut juga perata waktu atau ta'dil al waqt/ta'dil asy-syams yaitu selisih antara waktu kulminasi Matahari Hakiki dengan waktu Matahari rata-rata. Data ini biasanya dinyatakan dengan huruf "e" kecil dan diperlukan dalam menghisab awal waktu salat. Baca Susiknan Azhari, op.cit. hlm. 62.

${ }^{42}$ Muhyiddin Khazin, Ilmu Falak Dalam Teori dan Praktik, Yogyakarta : Buana Pustaka, cet 1, 2004, hlm. 67.

${ }^{43}$ Badan Hisab Dan Rukyah Departemen Agama, op.cit, hlm. 60. 
mencari waktu kota atau tempat yang dihitung dengan Waktu setempat $=($ Bujur Daerah - Bujur Tempat) : 15). ${ }^{44}$

\section{Alat Perhitungan}

Kata Logaritma diambil dari kata Algorismi yang berarti proses menghitung dengan angka Arab. Seseorang dikatakan "Algorist"jika menghitung menggunakan angka Arab. Para ahli bahasa berusaha menemukan asal kata ini namun hasilnya kurang memuaskan. Akhirnya para ahli sejarah matematika menemukan asal kata tersebut yang berasal dari nama penulis buku Arab terkenal, yaitu Abu Abdullah Muhammad Ibnu Musa Al-Khuwarrismi dibaca oleh orang Barat menjadi Algorism. Dalam bahasa Spanyol disebut dengan Guarismo dan dalam bahasa Portugis adalah Algarismo yang berarti digit. Nama al-Khawarizmi terkenal pada saat itu karena karyanya yang berisi tabel logaritma atau fartar logaritma pertama kali dalam buku yang berjudul Al-Jabar Wa al-Muqabilah. Di dalam buku tersebut terdapat tabel rincian trigonometri yang memuat fungsi sinus, cosinus dan kosinus serta konsep diferensiasi. $^{45}$

Dalam tabel Logaritma terdapat tiga fungsi trigonometri yakni sinus, cosinus dan tangen. Sinus adalah perbandingan sisi segitiga yang ada di depan sudut dengan sisi miring (dengan catatan bahwa segitiga itu adalah segitiga siku-siku atau salah satu sudut segitiganya $\left.90^{\circ}\right) .^{46}$

Logaritma adalah angka-angka yang menentukan martabatnya bilangan. Seperti $\log 1=0 ; \log 3=1 / 3 ; \log 9=1 ; \log 81=2$ dan seterusnya. Oleh karena angka-angka logaritma banyak sekali, maka yang biasa dipakai adalah angka-angka yang menjadi eksponen dari angka 10. Logaritma semacam ini disebut Briggsche logaritma, yaitu yang dijadikan dasar pokoknya $101=10 ; 102=100 ; 103=1000$ dan seterusnya. ${ }^{47}$

Selanjutnya untuk mencari logaritma bilangan-bilangan yang lain dapat dicari dalam sebuah daftar khusus. Seperti daftar briggsshe logaritma seperti karangan Dr. B Gonggrijp dan lain-lainnya.

Dalam daftar tersebut biasanya angka-angka penunjuknya tidak disebutkan. Dalam hal ini supaya dibubuhi sendiri dengan ketentuan bahwa bagi bilangan satuan penunjuknya 0 , bagi puluhan, penunjuknya 1 bagi bilangan ratusan, penunjuknya adalah 2. Bagi ribuan adalah 3 dan seterusnya. ${ }^{48}$

Tabel logaritma atau daftar logaritma adalah daftar angka-angka hasil perhitungan logaritma. Tabel logaritma ada banyak macam. Ada yang angka desimalnya hanya tiga angka, ada yang empat angka, lima angka dan seterusnya. Sementara perhitungan waktu salat dalam kitab Al-Khulashah fi al-Awqat alSyar'iyyah bi Al-Lugharitmiyyah yang digunakan adalah tabel logaritma lima desimal.

Dalam tabel logaritma dalam bentuk desimal berapa pun, terdapat tiga daftar yang biasanya digunakan dalam ilmu matematika. Pertama daftar logartima biasa.

${ }^{44}$ Angka 15 tersebut merupakan kaidah yang merupakan jarak di antara meridian-meridian yang menguasai setiap daerah itu besarnya $15^{\circ}$. Hal itu berarti bahwa perbedaan waktu di antara dua daerah yang berbatasan besarnya 60 menit atau tepat 1 jam. Uraian selengkapnya baca Abd. Rachim, op.cit, hlm. 55.

${ }^{45}$ Wahyu, 99 Ilmuwan Muslim Perintis Sains Modern, Yogyakarta: Diva Press, 2010, hlm. 27

${ }^{46}$ W. M. Smart, Tekt book on Spherical Astronomy, New York: Cambridge University Press, Edisi ke-6, 1980, hlm. 9.

47 KR. Muhamad Wardan, Kitab Ilmu Falak dan Hisab, Yogyakarta : al Maktabah al Mataramiyah, 1957, hlm. 60.

${ }^{48}$ Ibid 
Daftar ini berisi tentang hasil logaritma pecahan bilangan biasa dari 1 sampai 1000 . Seperti bilangan 5, 17, 140 dan lain-lain, maka akan terdapat angka pecahan. Misalnya bilangan 5. Logaritmanya adalah 0.69897. Bilangan 17 logaritmanya adalah 1.23045. Bilangan 140 logaritmanya adalah 2.14613. Angka yang berada di depan koma disebut penunjuk (karakteristik) dan angka sesudah koma disebut pecahan (mantisse). ${ }^{49}$

Kedua, daftar Goniometrische Functies (fungsi-fungsi goniometris). Ialah untuk menerangkan perbandingan-perbandingan antara sisi-sisi segitiga siku-siku. Dalam hal ini telah dibuatkan daftar yang cukup dengan ukuran besarnya sudut $0^{\circ}$ sampai $90^{\circ}$. Di dalam daftar tersebut terdapat angka-angka yang menunjukkan sinus derajat sudut. Demikian pula tangens, cosinus dan cotangensnya.

Angka-angka yang terdapat dalam Goniometrische Functies tersebut di atas adalah bilangan desimal, artinya jika akan menjumlah, mengalikan, mengurangi atau membagi angka-angka tadi harus juga dijumlah sebagaimana menjumlah angka biasa demikian. Demikian pula dalam mengurangi, mengalikan dan membagi. ${ }^{50}$

Cosinus dalam matematika diartikan sebagai perbandingan sisi segitiga yang terletak di samping sudut dengan sisi miring (dengan catatan bahwa segitiga itu adalah segitiga siku-siku atau salah satu sudut segitiganya $\left.90^{\circ}\right) .{ }^{51}$ Adapun nilai cosinus dalam kitab ini diistilahkan dengan qous ${ }^{52}$.

Tangen dalam matematika, tangen diartikan sebagai perbandingan sisi segitiga yang ada di depan sudut dengan sisis segitiga yang terletak di sudut (dengan catatan bahwa segitiga itu adalah segitiga siku-siku atau salah satu sudut segitiganya $\left.90^{\circ}\right) .^{53}$

\begin{tabular}{|c|c|c|}
\hline Program/kitab & $\begin{array}{c}\text { Hisab } \\
\text { Ephemeris }\end{array}$ & $\begin{array}{c}\text { Kitab al-Khulashah fi al-Awqat al- } \\
\text { Syar'iyyah bi al-Lugharitmiyyah yakni }\end{array}$ \\
\hline Waktu & & $11: 42$ \\
\hline Zuhur & $11: 40$ & 15.01 \\
\hline Ashar & $15: 01$ & $17: 32$ \\
\hline Maghrib & $17: 33$ & $18: 46$ \\
\hline Isya' & $18: 47$ & $04: 20$ \\
\hline Subuh & $4: 25$ & \\
\hline
\end{tabular}

Penentuan waktu salat dengan menggunakan tabel logaritma merupakan bagian rangkaian perkembangan metode dari klasik hingga modern. Sebelum menggunakan tabel logaritma, penentuan waktu salat masih menggunakan alat bantu peralatan klasik seperti jam istiwa' seperti dalam kitab syawariq al-anwar karya KH. Noor Ahmad. Ada juga yang menggunakan alat bantu rubu' mujayyab seperti dalam kitab ad-Durus al-Falakiyyah.

Hasil perhitungan dengan penggunaan tabel logaritma bisa dikatakan lebih teliti dibanding menggunakan alat bantu rubu' mujayyab,54 atau dengan

\footnotetext{
49 Ibid, hlm. 61

50 Ibid, hlm. 63

${ }^{51}$ W. M. Smart, op.cit, hlm. 9.

52 Muchammad Khumaidi Jazri, Op. cit, hlm. 4

${ }^{53}$ W. M. Smart, op.cit, hlm. 13

${ }^{54}$ Muhammad Ma'ksum bin Ali al-Maskumambangi, Badiah al-Mitsal fi Hisab al-Sinin wa al-
} Hilal, Surabaya : Maktabah Sa'ad bin Nashir Nabhan, tt. hal. 28. 
menggunakan jam istiwa'. Namun jika dibandingkan dengan perhitungan dengan alat bantu kalkulator scientific, tingkat ketelitian tabel logaritma masih di bawahnya karena nilai tabel logaritma selalu positif sehingga dalam perhitungan terdapat istilah mukhalafah dan muwafaqah yang sangat berpengaruh terhadap hasil perhitungan.

\section{E. Analisis Akurasi Perhitungan Waktu Salat dalam Kitab Al-Khulashah fi Al- Awqat As-Syar'iyyah bi Al-Lugharitmiyyah}

Dalam pendahuluan kitab Al-Khulashah fi Al-Awqat al-Syar'iyyah bi AlLugharitmiyyah penulis kitab tersebut Muhammad Khumaidi Jazry menegaskan bahwa dalam perhitungan waktu salat dalam kitab tersebut menggunakan alat bantu daftar logaritma lima desimal. Hal ini mempengaruhi dalam hasil perhitungan tersebut terutama dalam hal akurasinya. Oleh karena itu untuk mengetahui tingkat akurasinya perlu dibandingkan dengan hasil perhitungan dengan metode lain.

Untuk mengetahui akurasi hasil perhitungan, maka penulis membandingkannya dengan hisab waktu salat sistem ephemeris.

Berikut gambaran hasil perhitungan pada tanggal 21 Juni Semarang dengan lintang tempat sesuai data dalam kitab al-Khulashah fi al-Awqat al-Syar'iyyah bi alLugharitmiyyah yakni $6^{\circ} 59^{\prime} \mathrm{LS}$ dan $110^{\circ} 26^{\prime} \mathrm{BT}$.

Dari hasil perhitungan waktu salat dalam tabel di atas dapat disimpulkan bahwa terdapat selisih antara perhitungan kitab Al-Khulashah fi al-Awqat alSyar'iyyah fi al-Lugharitmiyyah dengan perhitungan hisab ephemeris. Akan tetapi selisih tersebut hanya satu menit atau dua menit. Selisih terbanyak terjadi pada perhitungan waktu subuh yakni selisih empat menit dengan program Shollu dan lima menit dengan perhitungan lain.

Untuk membuktikan apakah hasil hisab waktu salat dalam kitab dan perhitungan dengan program di atas sudah akurat atau belum maka perlu dilakukan pengecekan terhadap pergerakan matahari secara langsung.

Awal waktu Dhuhur dalam kitab ini menjelaskan bahwa waktu Dhuhur terjadi setelah matahari mencapai titik kulminasi atas yakni ditetapkan yang 
terjadi pada jam 12.00 ditambah daqaiq al-tamkiniyyah sebesar 3 menit 30 detik $^{55}$. Tambahan tersebut merupakan tambahan waktu yang diperlukan oleh gerak matahari sejak kulminasi sampai tergelincir. ${ }^{56}$

Untuk membantu membuktikannya dibutuhkan tongkat istiwa sebagai penanda bayangbayang. Menentukan secara tepat tempat jatuhnya bayang-bayang ujung tongkat tersebut, merupakan suatu hal yang sangat sulit, dalam hal ini bisa disebabkan tidak kelihatan tajam pada ujung bayang-bayangnya. Namun bila mata cukup teliti, maka penentuan tinggi matahari dengan cara yang sederhana itu dapat dilakukan dengan hasil yang cukup memuaskan.

Bayang-bayang dapat berada pada arah selatan tongkat atau arah utaranya, tergantung data deklinasi dan lintang tempat. Tongkat istiwa' tidak mempunyai bayang-bayang, jika matahari berkulminasi di titik zenith yaitu jika nilai deklinasi = nilai lintang tempat. ${ }^{57}$

Pengecekan awal waktu Ashar dapat juga dilakukan dengan mempergunakan tongkat istiwa', yaitu ketika matahari bergerak ke arah barat dengan wujud bayang-bayang yang sama dengan benda yang berdiri tegak lurus, lalu ujung bayang-bayang tersebut bergerak perlahanlahan ke arah timur. Selanjutnya, ukuran panjang bayang-bayang tongkat berangsur-angsur bertambah dengan sepanjang tongkat itu sendiri, bila dibandingkan dengan panjangnya sewaktu matahari sedang berkulminasi. Pada saat itulah waktu Ashar mulai masuk. ${ }^{58}$

Pengecekan awal waktu Magrib yaitu saat matahari terbenam/piringan atas dan matahari terbit/piringan bawah matahari telah berada di bawah ufuq atau kaki langit. Hal ini dapat dilakukan dengan mempergunakan teropong atau mata telanjang dengan bantuan alat, melihat saat piringan atas matahari menyentuh garis ufuk. Sebaiknya yang dijadikan ukuran ufuk adalah permukaan laut atau dataran rendah yang luas seperti padang pasir atau padang rumput.

Selanjutnya pengecekan waktu Isya sangat diperlukan pengalaman yang berkali-kali sebab memperhatikan hilangnya warna merah di ufuk barat bukanlah pekerjaan yang mudah. Hilangnya warna merah di ufuk barat tidak saja disebabkan posisi matahari sudah $17^{\circ}$ di bawah ufuk, ${ }^{59}$ tetapi dapat juga karena tiba-tiba cuaca di sekitarnya menjadi mendung. Hilangnya warna merah sebagai tanda awal Isya adalah jika posisi matahari $17^{\circ}$ di bawah ufuk, ${ }^{60}$ dan hal ini sulit di amati kecuali oleh orang-orang yang telah berpengalaman matang.

Adapun pengecekan awal waktu Subuh sama sulitnya dengan pengecekan waktu Isya. Terbit fajar sebagai tanda masuk waktu Subuh sulit diamati kecuali oleh para ahli yang telah berpengalaman. Namun demikian pengecekan itu perlu juga dilakukan sebagai usaha mencapai kebenaran.

Dari keterangan hasil di atas maka perhitungan waktu salat dengan metode yang terdapat dalam kitab ini dapat dijadikan sebagai acuan akan tetapi masih dibutuhkam koreksi ke waktu daerah yang dihitung. Untuk membuktikan akurasi kitab ini maka diharuskan untuk melakukan pengecekan langsung terhadap posisi matahari, di mana waktu tersebut tidak sama dengan waktu resmi atau waktu yang sudah umum digunakan. Dengan demikian, waktu yang sama (waktu daerah) untuk tempat-tempat yang berbeda umumnya tidak menunjukkan kedudukan matahari

55 Muhammad Khumaidi Jazry, Al-Khulashah Fi al-Awqat al-Syar'iyyah Bi al-Lugharitmiyyah, Gresik : Mawar, 1995, hlm. 20

${ }^{56}$ Departemen Agama RI, Pedoman Penentuan Jadwal Waktu Shalat Sepanjang Masa, Jakarta : Direktorat Pembinaan Badan Peradilan Agama Islam, 1994, hlm. 7.

${ }^{57}$ Abd. Rachim, op.cit, hlm, 15.

${ }^{58} \mathrm{Ibid}, \mathrm{hlm} .24$.

59 Saadoe'ddin Djambek, Shalat dan Puasa di Daerah Kutub, Jakarta : Bulan Bintang, t.th, hlm. 10.

${ }^{60}$ Ibid. Lihat juga dalam Muhyiddin Khazin, op.cit, hlm. 92. 
yang sama. Oleh karena itu, untuk menentukan kedudukan atau ketinggian matahari pada suatu saat di suatu tempat, sistem waktu daerah tidak bisa digunakan secara langsung. Dalam hal ini harus digunakan sistem waktu matahari hakiki.

\section{Kesimpulan}

Berdasarkan pembahasan dan analisis yang telah dilakukan pada beberapa bab tersebut di atas, penulis dapat mengambil kesimpulan sebagai berikut:. Pertama, Metode penentuan awal waktu salat dalam kitab Al-Khulashah fi al-Awqat al-Syar'iyyah bi al-Lugharitmiyyah dengan alat bantu tabel logaritma masih memberlakukan konsep muwafawah dan mukhalafah karena prinsip logaritma selalu bernilai positif sehingga nilai negatif ditiadakan. Untuk membedakan pemakaian rumus tersebut dapat dilihat dari nilai negatif/positif pada data-datanya (lintang dan deklinasi). Perhitungan akhir dalam kitab ini juga masih menghasilkan waktu hakiki. Maka untuk menghasilkan perhitungan waktu salat daerah maka diperlukan data-data lainnya. Kedua, Selisih hasil perhitungan dengan kitab Al-Khulashah fi al-Awqat al-Syar'iyyah bi al-Lugharitmiyyah dengan Hisab Kontemporer dan program adalah satu dan dua menit. Selisih terbanyak terjadi pada waktu subuh yakni lima menit.[] 


\section{Daftar Pustaka}

Badan Hisab Dan Rukyah Departemen Agama, Almanak Hisab Rukyat, Jakarta: Proyek Pembinaan Badan Peradilan Agama Islam, 1981

Departemen Agama RI, Al-Qur'an dan Terjemahnya, Surabaya : CV. Pustaka Agung Harapan, 2006,

Jakarta: Direktorat Pembinaan Badan Peradilan Agama Islam, 1994.

Imam Fakhruddin Muhammad bin Umar bin Husain bin Hasan bin Ali Tamimy al-Bakri al-Razy al-Syafi'i, Tafsir al-Kabir au Mafatih al-Ghoib, Beirut - Libanon : Dar al-Kutub alAlamiah, jild VI

KR. Muhamad Wardan, Kitab Ilmu Falak dan Hisab, Yogyakarta : al Maktabah al Mataramiyah, 1957.

M. Quraish Shihab, Tafsir Al-Misbah, Vol. 8, Jakarta : Lentera Hati, Cet 1, 2002

Muhammad Khumaidi Jazry, Al-Khulashah Fi al-Awqat al-Syar'iyyah Bi alLugharitmiyyah, Gresik : Mawar, 1995

Muhammad Ma'ksum bin Ali al-Maskumambangi, Badiah al-Mitsal fi Hisab al-Sinin wa al-Hilal, Surabaya : Maktabah Sa'ad bin Nashir Nabhan, tt

Muhyiddn Khazin, Kamus Ilmu Falak, Yogyakarta: Buana Pustaka, 2005

Nizham al-Din al-Hasan bin Muhammad bin Husain al-Kummy al-Naesabury, Tafsir Gharaib al-Qur'an wa Raghaib al-Fur'qan, Beirut - Libanon : Dar al-Kutub al-Alamiah, jilid II Saadoe'ddin Djambek, Shalat dan Puasa di Daerah Kutub, Jakarta : Bulan Bintang, t.th.

Slamet Hambali, Ilmu Falak 1, Penentuan Awal Waktu Shalat \& Arah Kiblat Seluruh Dunia, Muhyiddin Khazin, Ilmu Falak Dalam Teori dan Praktik, Yogyakarta : Buana Pustaka, cet 1,2004

Susiknan Azhari, Ensiklopedi Hisab Rukyah, yogyakarta ; Pustaka Pelajar, cet II, 2008

W. M. Smart, Tekt book on Spherical Astronomy, New York: Cambridge University Press, Edisi ke-6, 1980.

Wahyu, 99 Ilmuwan Muslim Perintis Sains Modern, Yogyakarta: Diva Press, 2010 